\title{
EVALUATION OF SOUTH SULAWESI ON STUDENT DEVELOPMENT AND TRAINING PROGRAM
}

\author{
Hasyim*, Herman,** \\ State University of Makassar \\ hasyimaltaf@yahoo.co.id
}

\begin{abstract}
Abstrac
The purpose of this study is to provide reports on the advantages, weaknesses and recommendations related to the program to become better at PPLP in South Sulawesi in terms of context, input, process and product (CIPP) with qualitative and quantitative research approach. The instrument of this research is observation, documentation and questionnaire arranged to collect quantitative data, while interview guidance instrument is arranged to collect qualitative data. The data collected from the elements of trainers, athletes, and administrators were analyzed quantitatively descriptive percentage using microsoft excell and qualitative data analysis triangulation. The result of South Sulawesi PPLP evaluation is statistically from context variable, input, process, product as a whole has been done well with $70.30 \%$ percentage. The evaluation of context variables shows excellent results with a $90 \%$ percentage. The input evaluation showed good results with the percentage of $61.40 \%$. The results of the evaluation process showed good results with a percentage of $77.46 \%$. Product evaluation results show considerable results with $52.34 \%$ percentage.
\end{abstract}

\section{Keywords: Program Evaluation, CIPP, PPLP Coaching South Sulawesi.}

Sports achievement is a sport that is designed to print athletes with high performance so as to achieve maximum performance at the regional, national and international levels. Sports achievements achieved by Indonesia in the last five years show a declining trend, the last in the event of Rio in Brazil in 2016. Indonesia only won one gold medal and finished 46th. This is a basis for conducting evaluation activities. In this study, focused on the achievement of martial sports achievement which is one of the leading sport branch of Indonesia. In fact it still has not shown optimal results at the Rio 2016 Olympics event in Brazil.

The coaching performance of athletes in Indonesia is the development of national sports that are interconnected with each other. Achievement of achievement in international event can not be separated from the preparation and coaching program of athletes at the basic level, that is at the institution of coaching the achievement of student athletes through Student Development and Training program (PPLP). With a good coaching on the build up of the national sports base, the tendency will boost the achievement of national sports at a better international event in the future, especially the sport martial arts.

South Sulawesi is one of the provinces of Indonesia that has advantages in the sport martial arts. Based on the results of data recapitulation of South Sulawesi Dispora in South Sulawesi PPLP achievement at Popnas in 2011 at the National Student Sport event in Riau Province where PPLP South Sulawesi won 3 (three) gold medals, 3 (three) silver medals, and 3 (three) bronze medals . In the next Popnas held in 2013 in the Province of DKI Jakarta where PPLP South Sulawesi won 4 (four) silver medals and 3 (three) bronze medals. As for the year 2014 POPWIL medal achievement 2 (two) gold, 4 (four) silver and 3 (three) bronze.

This research is focused on performance evaluation activities in the sport martial arts as the leading sporting branch of PPLP South Sulawesi Province which often contribute national athletes at International event. This becomes interesting to be disclosed because of the achievement trend in the sports branch is experiencing a dynamic or fluctuating achievement this is allegedly has several factors that cause quality of human resources and supporting facilities. One symptom of the phenomenon in the event POPNAS 2013 martial arts sport is only able to achieve 1 silver medal. In boxing sport at POPNAS 2013 only able to reach 1 silver medal. 
Based on the downward trend of Indonesian contingent achievement of martial arts sport at Rio 2016 and the trend of declining achievement of student athletes PPLP South Sulawesi, it is necessary to do evaluation related to coaching program. The evaluation conducted in this study is not only a routine activity, but also wants to reveal the various components related to the training program of the whole students so that they can give a complete picture of PPLP, analyze their weaknesses and strengths, and make the right contribution to the sustainability of the program. Therefore the researchers used the CIPP model evaluation approach (context, input, process, and product) by Stufflebeam (2007: 4).

In case the context researchers will see policies related to PPLP, among them; 1) Government policy on PPLP in this case Dispora policy so that PPLP South Sulawesi can grow. 2) PPLP Leadership Policies that can synergize between government policies and implementing policies. In addition to that need to be considered from the context is the athlete's own needs in following the PPLP program in order to improve the performance of athletes. In terms of input, researchers discuss the recruitment of athletes and trainers, of course in recruitment must follow some tests and rules that have been set by the organizers so that athletes and trainers can really improve the quality of sports in Indonesia, especially in Southern Sulaswesi. In addition, the support of facilities and infrastructure is also important, because the facilities and adequate infrastructure will certainly facilitate athletes in practice. So evaluating in the field of facilities and infrastructure is also very important.

In terms of process, researchers evaluated the exercise for athletes, exercise evaluation, promotion and degradation systems, and the presence of support personnel. All pertinent about the process is important for evaluation to know the effectiveness of the exercise. A good practice execution process is in accordance with pre-planned planning with a pronsip of flexibility based on athletic development. Compliance and synchronization of exercise exercises have an important role in achieving training targets.Segi product, researchers will discuss about the achievement of athletes, because this program is implemented to improve the performance of South Sulawesi martial arts at the Naional event. Products that become the main indicators in the product include physical quality and medal achievement.

With this evaluation research is expected to provide information and recommendations related to the training program of athletes at martial arts at the elementary level in South Sulawesi, which nanatinya impact on the improved PPLP program and increasing achievement of South Sulawesi athletes in particular and Indonesia in general.

The Nature of Evaluation

There are at least 26 evaluation approaches that are divided into five categories, including: pseoudoevaluation, quasi-evaluation studies, improvement-and accountability-oriented evaluation, social agenda and advocacy, and eclectic evaluation (stufflebeam \& Shinkfield, 2007). Evaluation conducted in this study aims to membeproleh information oriented on the advantages, weaknesses, opportunities and threats objectively and thoroughly so as to generate recommendations to improve the quality of the program.Thus, the appropriate approach is the improvement-and accountability-oriented evaluation approach, including the misunderstanding of CIPP evaluation model (Context, Input, Process, Product).

Evaluation activities are the collection of meaningful information to obtain an overview of something, then provide recommendations based on the findings of information obtained. Program, is a form of activities that are organized and systematically organized to achieve certain goals. A "program" is often planned and executed with a package of evaluations. Program evaluation is a very effective activity to improve program quality in the future. The program evaluation collects information about a program or some aspect of the program to make decisions about the program. Program evaluation measures things to the extent that goals can be realized well.

Roberts and Greene, (2009: 473) state that program evaluation is essentially the application of scientific social research methods to access planning, implementation, program outcomes and social interventions. There are methods and principles of applied research. There is a formulation of the problem described on which part will be evaluated and how the evaluation is focused.

According to Law No. 3 of 2005 on National Sport System. In creating the seeds of national sports achievements through sports education can be achieved with PPLP institutions throughout the region. With PPLP will bring junior athletes who can ultimately continue the struggle of the senior 
sportsmen in raising the Red and White at the international championship (Ministry of Youth and Sport, 2011:3).

The CIPP evaluation model proposed by Stufflebeam \& Shinkfield (2007: 333) is a decisionoriented evaluation approach structured to provide assistance to administrators or decision-making leaders. The results of the evaluation will provide an alternative problem solving for decision makers. CIPP evaluation model consists of: conteks, Input, process, and product

The product results are inputs that can be used for system changes that have been used. The following picture shows the flow with the CIPP model:

Gambar 1: Model CIPP

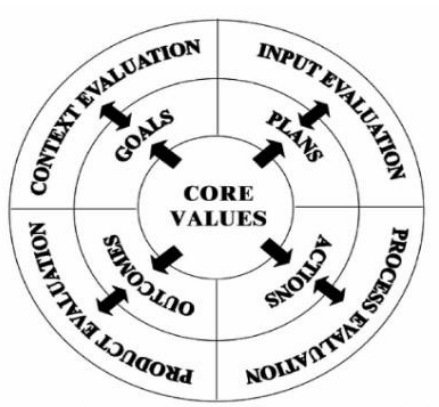

Stufflebeam dan Shinkfield, Evaluation Theory, Models, dan Applications (United States of America, 2007: 333)

in general, the purpose of this study is to provide information and recommenda- tion of the Indonesian student athletes coaching program at the level of local coaching in order to become better that impact on the improvement of national sports achievement in the international arena. In particular, this evaluation study aims to find out about the implementation of PPLP South Sulawesi achievement program in the sport martial arts. The extent to which the success of the program in achieving the goals that have been set. In addition, evaluations made on the implementation of PPLP achievement program are also expected to generate inputs for program organizers in making decisions regarding efforts to improve the relevance, quality and effectiveness of future program implementation.

The results of this study will prove that, student athlete coaching program is something that needs to be given more attention to support the birth of a new professional athletes quality. Young athletes training programs designed and implemented need to be evaluated for self improvement. Because the program is a system of many components, then the evaluation activities serve to maintain harmonization between components, for the program more effective and efficient. This research is a bit of a picture related to it.

\section{METHOD}

The research method used is quantitative descriptive and qualitative methods of triangulation, where the goal is to make accurate interpretation of the characteristics of the object under study. The approach used in this program evaluation study is the CIPP Model (Stufflebeam, 2007: 4) in terms of context, input, process and product stages. This means to obtain accurate and objective information and compare what has been achieved from the PPLP development program in South Sulawesi with what should be achieved based on predetermined standards. Quantitative data analysis of descriptive percentage is done by processing the result of questionnaire using formula $\mathrm{P}=(\mathrm{X} / \mathrm{Xi}) \times \mathrm{N}$ with microsoft excell. The result of percentage analysis is then described to be a conclusion. While quantitative data analysis is done by triangulation by tracing and matching quantitative data with the findings of observation, interview and documentation.

\section{Evaluation of all CIPP variables Table 1. Overall Data of CIPP Variables}




\begin{tabular}{|l|c|l|l|l|l|l|}
\hline Variable & $\begin{array}{l}\text { Acquisiti } \\
\text { on value }\end{array}$ & $\begin{array}{l}\text { Max } \\
\text { Value }\end{array}$ & Percentage & Category & $\begin{array}{l}\text { Average } \\
\text { Percentage }\end{array}$ & Category \\
\cline { 1 - 5 } Context & 90,00 & 100 & $90,00 \%$ & Very good & & \\
\cline { 1 - 5 } Input & 61,40 & 100 & $61,40 \%$ & Good & \multirow{2}{*}{$0,30 \%$} & Good \\
\hline Proses & 77,46 & 100 & $77,46 \%$ & Good & & \\
\cline { 1 - 4 } Produk & 52,34 & 100 & $52,34 \%$ & Enought & & \\
\hline
\end{tabular}

The following is a bar chart to clarify the overall results of CIPP variables in PPLP sports martial arts in South Sulawesi.

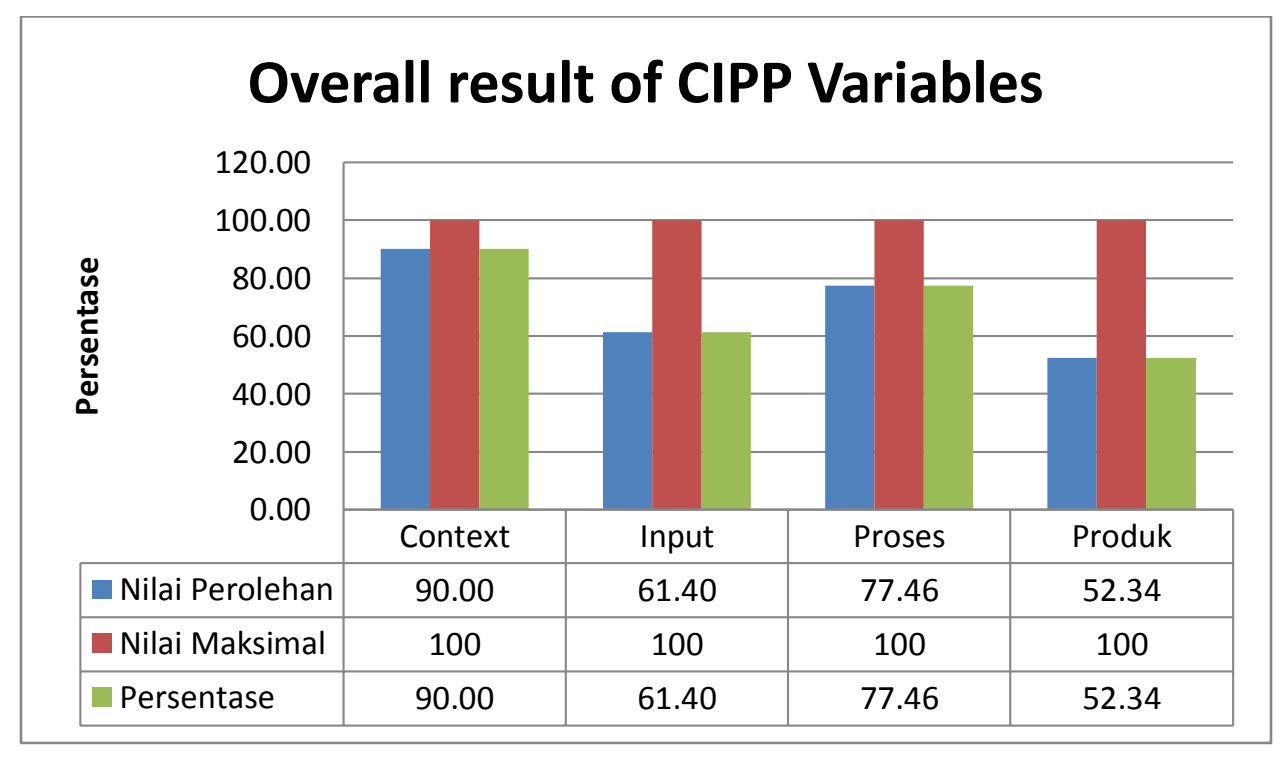

Figure 2. Overall Results Bar Diagram of CIPP Variables

Based on table 2 above, the results of the overall evaluation of CIPP variables on Context variables obtained an average percentage yield of $90 \%$ that entered in the category of Very Good. In variable of Input get result of average percentage equal to $61,40 \%$ entering in Good category. In the Process variables get the average percentage of $77.46 \%$ that goes in the Good category. In the Product variables get the average percentage of $52.34 \%$ of the results entered in the category Enough. As for the overall CIPP variables obtained the average percentage of $70.30 \%$ that fall into the Good category.

\section{DISCUSSION}

\section{Context Evaluation}

\section{A. On Government Policy}

In the context of government policy, there are three main aspects, based on the result of quantitative analysis with the percentage shows the result from the aspect of the formulation of the goal of the coaching program gets the percentage of $84 \%$ which means very good, the implementation aspect of the coaching gets the percentage of $80 \%$ which means very good, and the implementation aspect Coaching earned a percentage of $96 \%$ which means very good. The following is an evaluation of the government policy context in the bar chart; 


\section{Context Bar chart of Government Policy}

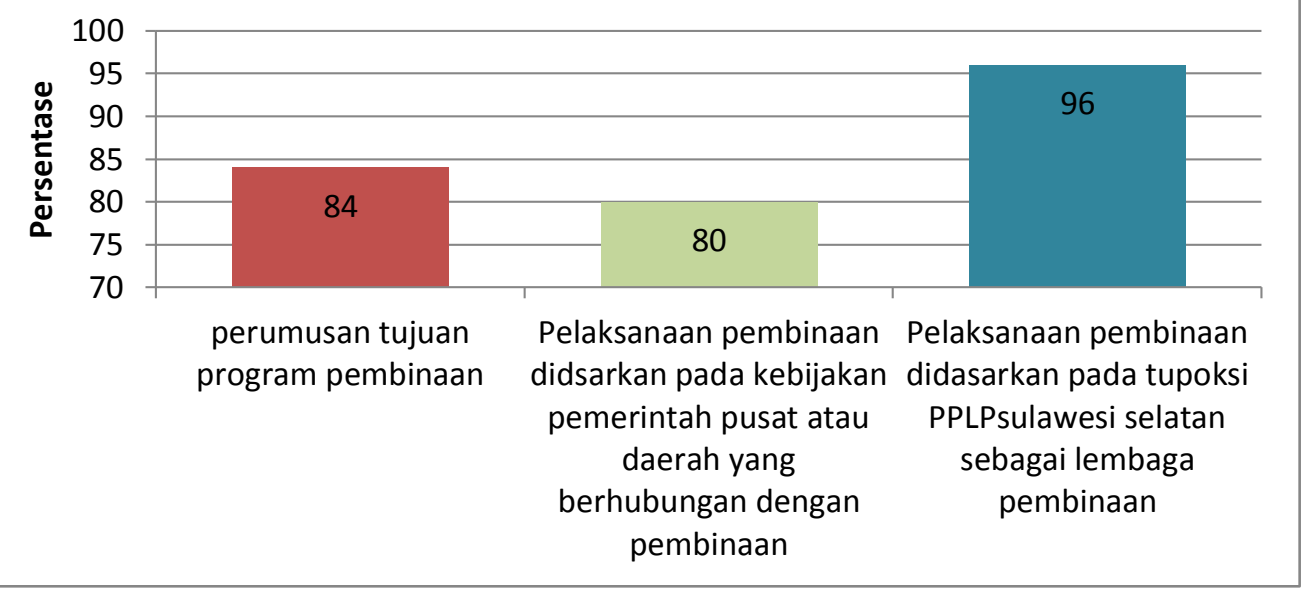

Figure 3. Bar chart Results of Variable Context of Government Policy

Based on quantitative data with questionnaires obtained by researchers, aspect of objective formulation, distribution of tupoksi, and conformity with local government objectives at South Sulawesi Provincial Dispora Dispensation Plan as presented above, overall policy context of government get very good result with percentage $86,67 \%$. Thus, it can be concluded statistically the context variable of government policy aspect very well

The Purpose of Coaching Implementation

In the context of the context of the implementation of coaching there are three main aspects, based on the results of quantitative analysis with the percentage shows the results of the design aspect of the program based on needs and targets get $96 \%$ percentage which means very good, the implementation aspect obtained a percentage of $88 \%$ which means very good, Associated with the previous result obtained a percentage of $96 \%$ which means very good. The following is an evaluation of the government policy context in the bar chart;

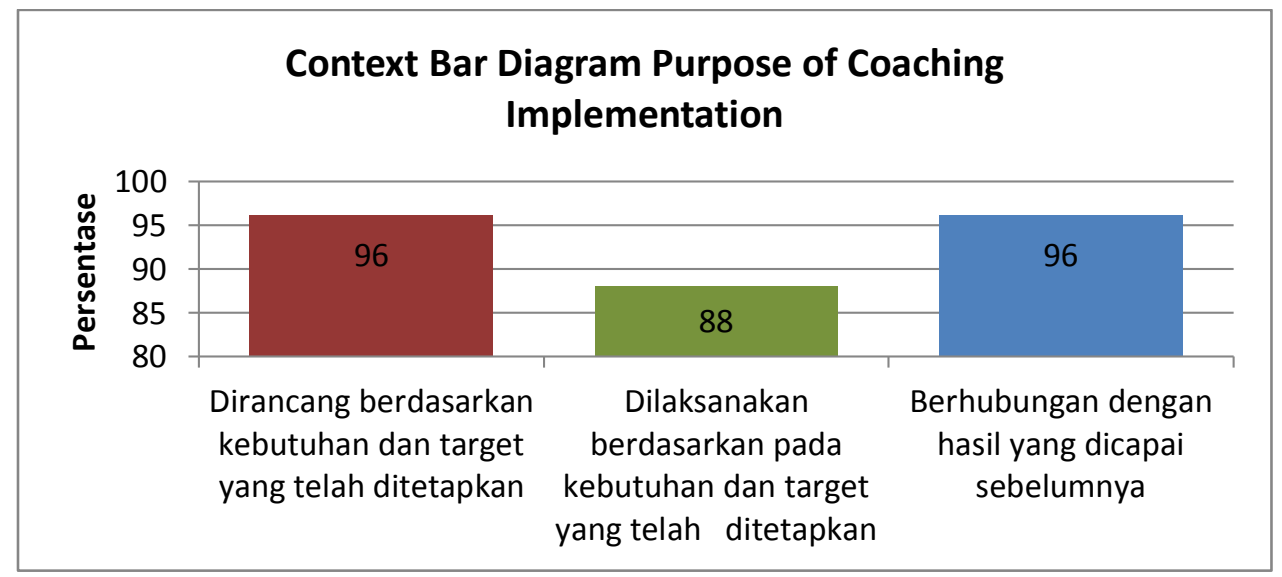

Figure 4. Context Diagram Results Context Variables Objectives Implementation Guidance However, based on the results of observations and interviews in this study indicate that the goal of PPLP athlete training program has not run well where the sport has not been able to meet the targets that have been given by managers and managers do not give sanctions to the coach itself if the target is not 
achieved. It can be concluded from the above opinion that the main purpose of coaching achievement in PPLP is actually education to achieve student's sporting achievement early on.

\section{Branch Office Compatibility}

This sports branch is in accordance with the characteristics of the area itself and athletes who netted in accordance with the age of students between 14 years to 16 years where this age is a productive age. The sports branches contained in PPLP are in accordance with the student's age characteristics, whether individual or team sports. The process of sports coaching must be adapted to the potential and culture in accordance with the regional superiority, so that the process of coaching that is made has been aligned with the characteristics of an area.

\section{Recruitment of Athletes}

The importance of the athlete recruitment process is an absolute matter. The ability of the selection of children will affect the level of coaching PPLP in finding the potential ability and capability motor skills are good. Therefore a transparent, honest, valid and scientific selection process is required. With a good selection process will be netted students who have a good motor in accordance with the sports branch that will be developed.

\section{Trainer's Recruitment}

The implementation of recruitment is still obtained by trainers who have not understood about making an exercise program. Coaches sent by the board are so limited that the coach remains in the recruitment of a trainer who understands the training program, and so far the coach still uses his experience as an athlete and pours his training into his athletes.

\section{Feasibility of Facilities and Infrastructure}

Facilities and Prasarasana that meet the standards greatly affect the improvement of achievement. Facilities and infrastructure PPLP South Sulawesi is far from what is expected in accordance with what is conveyed by the head of field coaching. The trainers and athletes also expressed the same thing that the existing means and parsaranas are far from what is expected. Therefore the facilities and infrastructure of South Sulawesi PPLP sebahagian need no rejuvenation so that athletes can practice well. Quantitative data on the evaluation of the feasibility of facilities and infrastructure consists of three aspects of assessment, among others related to the quality of facilities based on responses from athletes obtained a percentage of $72.5 \%$ which means good, $67 \%$ means good means of quantity, while the training infrastructure supports $69.5 \%$ Means good. So overall get a percentage of $69.67 \%$ which means good.

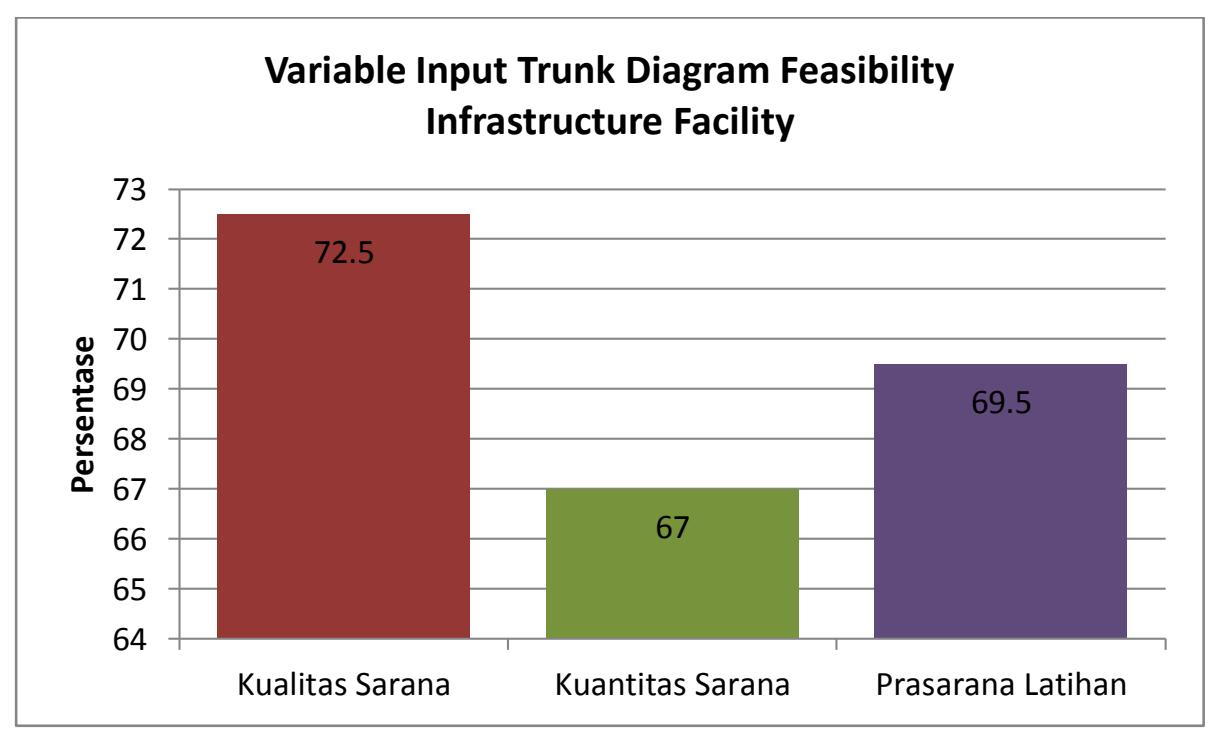


Figure 5. Bar Diagram Results Input Variables Feasibility Infrastructure Facility Exercise

Quality Coach and Assistant Coach

Questionnaire data related to the quality of trainers and assistant trainers are still in enough category with a percentage value of $53.13 \%$. Thus it can be concluded that the need for improvement in terms of HR trainers and assistant coaches. In collecting quality evaluation data of trainers, it is done by giving a questionnaire designed to know four main aspects that must be owned by a trainer and assistant trainer, among others, educational background, linieritas education with sports, licenses owned and selfdevelopment activities of trainers. Based on the result of questionnaire analysis, it is found that from the aspect of educational background of trainer and assistant coaches in accordance with the field of training obtained a percentage of $57.5 \%$ which means that the category is sufficient, the linearity of education with the sport gets the percentage of $40 \%$ which means good enough, the license Owned by a percentage of $52.5 \%$ which means quite good, and self-development activities get a percentage of $62.5 \%$ which means good. The following are presented in the stem diagram of the evaluation results of the quality of the trainers and the assistant coaches;

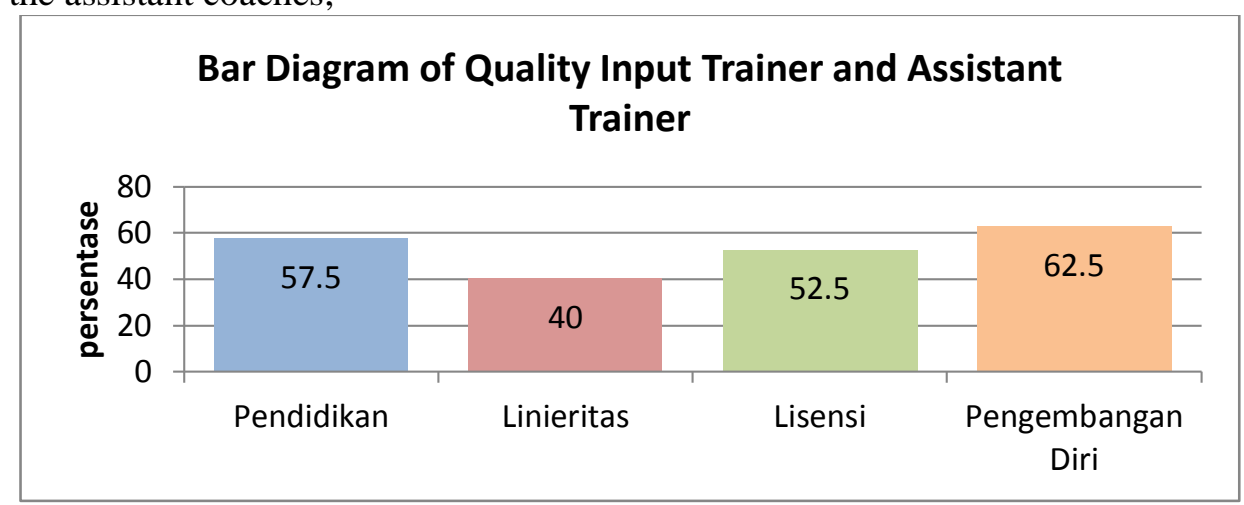

Figure 6. Bar chart Results of Input Variables Quality of Trainers and Assistant Trainers Financing of Coaching Implementation

Special financing for athletes has proceeded in accordance with the guidelines but the budget disbursement process sometimes faces obstacles where the coach program is hampered by delayed funding from the center, some of the trainer's programs do not go according to the planned schedule.

\section{Process Evaluation}

The results of the response that has been in that the trainers, assistant coaches and athletes in the category of good with a percentage of $76.64 \%$, this proves that the training program is in accordance with the characteristics of sports in PPLP South Sulawesi and scientific. Thus, it can be concluded that the results The response of trainers and athletes proves that South Sulawesi's PPLP trainers apply the exercises according to systematic and scientific training periods. While in more detail the evaluation aspect of the implementation process of the exercise program can be seen in the following bar chart; 


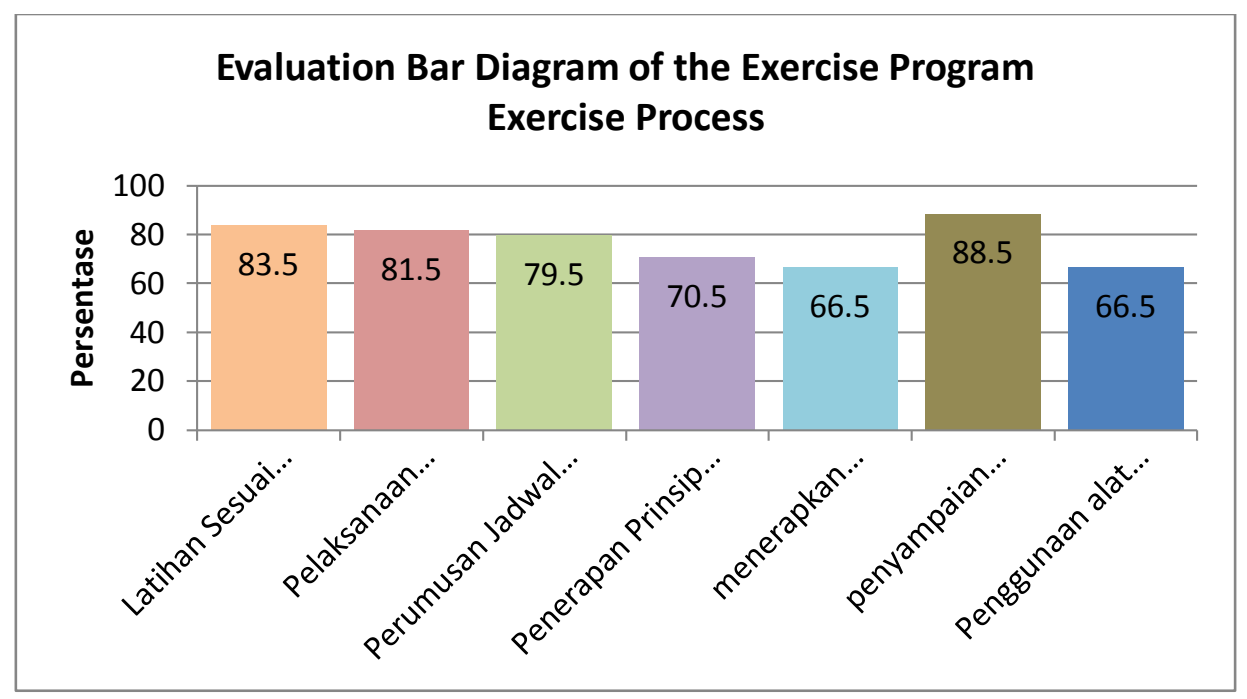

Figure 7. Bar chart Results Results Process Variables Execution Program

\section{Activities Athletes}

Questionnaires that have been distributed to athletes get good results with a percentage of $75.28 \%$. Thus, it can be concluded that the athlete has carried out the trainer training program well and orderly, however the percentage obtained by the athlete is still included in the middle percentage amount (middle value of good interval), therefore should be re-enhanced the quality of athlete training.

In more detail the evaluation aspect of the athlete's activity process can be seen in the following bar chart;

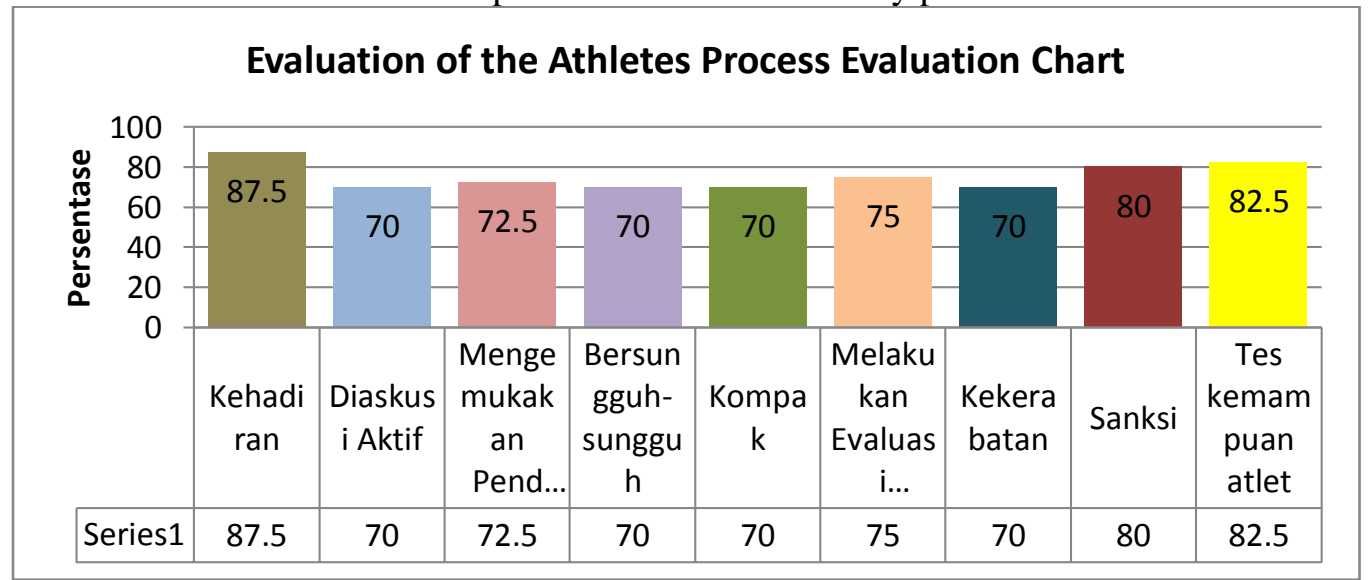

Figure 8. Diagram of Results of Variable Varieties of Athletes Activities Process

\section{Coach Activities}

On the coach and assistant coach obtained good results with a score of $80.47 \%$. Thus it can be concluded that the trainer has implemented the exercise in accordance with the training program that has been designed previously. Even the percentage value obtained by coaches and assistant coaches is approaching the category very well. In more detail the evaluation aspect of the trainer activity process can be seen in the following bar chart; 


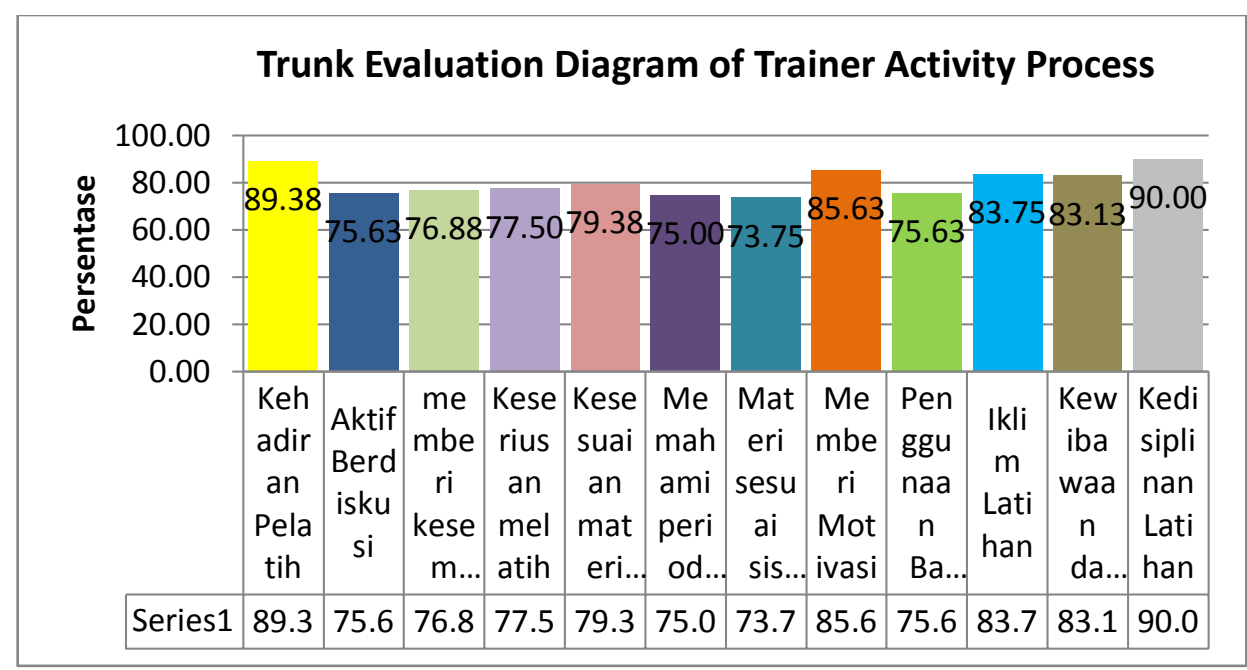

Figure 9. Bar chart Results Results Process Variables Process Trainers

Promotion and Degradation System

Based on the results of the interviews found that the promotion and degradation system for athletes who are built is intended to maintain competition between athletes PPLP South Sulawesi so as to create the dynamics of a positive competition in order to find the best. With the implementation of degradation promotion system makes athletes continue to be motivated to improve the quality so as not to be eliminated as athletes PPLP South Sulawesi.

Nutrition

In the process of making the food menu is not made by referring to the principle of nutrition rules for athletes. Provision of nutrition menu for athletes by way of tendering. Then the process of ordering the menu does not consider the appropriate nutrition athletes because the manager for the provision of food menu for athletes PPLP not come from someone who has competence in the field of nutrition. So the manager. More nutritional menu to the process of food menu with a standard level. Coordination. Results of interviews with PPLP managers obtained results always coordinate with KONI South Sulawesi every recruitment activities coaches and athletes. Coordination of PPLP managers with the government, mass media, KONI, and Pengprov sports has been well under way, but PPLP managers must keep trying to encourage sponsors and private parties to assist in the promotion of PPLP.Welfare It should be aware of what is happening in PPLP in South Sulawesi is also happening throughout Indonesia, this is due to the lack of budget from the government in coaching athletes and coaches. The level of welfare is still very minimal and even there is no guarantee in old age so this is one of the factors causing the minimum achievement of athletes in the national peninsula.

\section{Evaluation Of Products}

Based on the results of interviews and documentation studies, it was found out that the training programs planned by PPLP trainers were inconsistent, both implemented by the head of dormitory and PPLP trainers themselves. From the results obtained, that the head of the dormitory always provide the portion of exercise given to athletes outside of the exercise program. This results in a negative impact on the athletes during the training program in the afternoon due to physical fatigue factors given in the morning. In addition, the athlete in following the training program provided by the coach can not be followed perfectly because the nutrient obtained is not balanced with the portion of the exercise and this has an impact on the training. Athletes more easily experience fatigue that affects the performance degradation, especially VO2Max and appearance when competing. While in terms of medal achievement in the arena of the national Champion starting in 2012-2014 obtained the result of a decrease in achievement. Based on the quantitative data obtained by researchers from the documentation study 
obtained the results of $51.74 \%$ percentage included in the category enough. When observed from the context, input and process results, all of these variables have no serious problem, even in the context of obtaining excellent results, the inputs get good results, and the process is also good. In the product variables, actually have obtained good results, because there are some athletes who won medals in each championship. But the main problem with the medal achievement product is the inconsistent medallion yield and tend to decrease in 2014, so from the analysis of quantitative data is categorized enough. The following product evaluation data is presented in the form of bar charts;

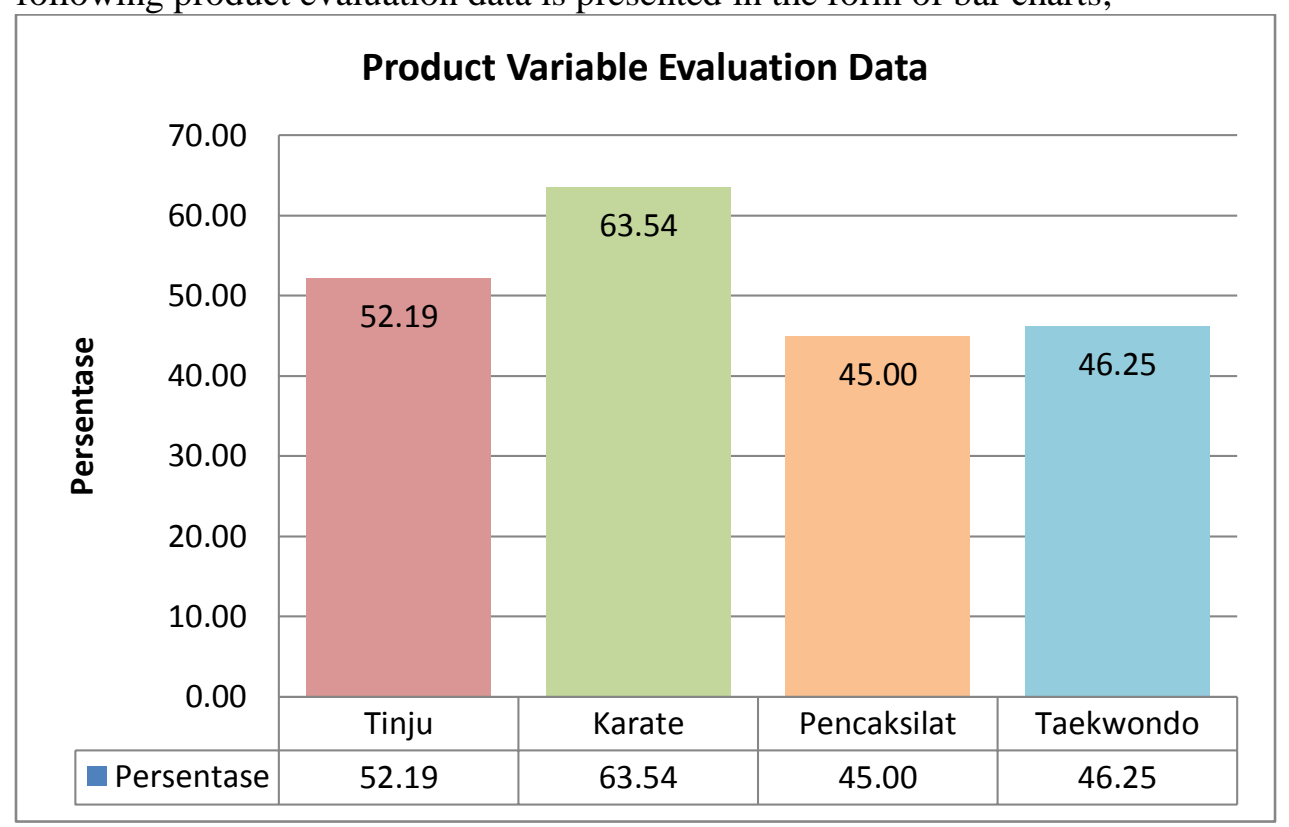

Figure 10. Diagram of the Product Variable Bar

Based on the results of the evaluation, the researcher recommends the following: the process variables become the main focus in this evaluation activity, found various incompatibilities between the planned training program in the context with the implementation of the field, the trainer must observe the process of conducting the exercise in accordance with the documentation material on Related contexts. In the process of monitoring athlete progress, it needs to be planned carefully and scheduled test and simulation activities so that athletes progress well recorded. Student athlete coaching process is important in the continuity of achievement at professional level in the future, therefore there should be follow-up athletes who have the potential to continue fostered continuously to achieve its best performance from time to time. Student performance athletes in Indonesia are scattered in various regions, local policy is very determining the fostering of a particular sport that became seeded, in general the local government will focus and provide maximum assistance to the regional flagship sport, it is not wrong, but will result in unequal Coaching on every sport, should the government pay attention to the system of equity of coaching in every sport so that all athletes get coaching that is equally qualified.

\section{The evaluation of contexts}

\section{CONCLUSION}

The evaluation of the context in the coaching of PPLP Dispora of South Sulawesi in martial sports has been very good. The strategic plan made by the board of PPLP Dispora of South Sulawesi has been in accordance with the legal basis and policy of PPLP development nationally. Contextual evaluation in terms of government policy, Dispora gives special attention both in the form of policies that lead to the improvement of athlete achievement as the peak of the development of sport nursery achievement in South Sulawesi. The purpose of the implementation of PPLP Dispora coaching South Sulawesi statistically shows very good results, but from the data interviews and observations indicate that the goal of PPLP athletes development program has not run well because the sport has not been able to 
meet targets provided by managers and managers do not give sanctions to Trainer itself if the given target is not achieved

\section{Input Evaluation}

Evaluation of inputs on martial sports include athlete recruitment, recruitment of trainers, quality of trainers and assistant coaches, feasibility of infrastructure and financing of coaching. Athletes recruitment statistically get good results. However, based on the results of interviews and observations on the selection of PPLP athletes in South Sulawesi sport martial arts has not run well where the athlete has not reached the standard set by the manager one of them is a physical test, especially on endurance tests by using BEDD candidate test athletes PPLP South Sulawesi Has not reached the established standard and ultimately the athlete remains pass. In the process of recruitment of trainers from the results of interviews and documentation studies of recruitment is still obtained trainers who do not understand the exercise program. Coaches sent by the board are very limited, so the coach remains in the recruitment given the lack of a coach who understands the training program, and so far the coach still uses his old experience while being an athlete and poured in training to the athlete he guides.

The quality of trainers and assistant coaches owned by PPLP Dispora South Sulawesi is statistically yielding considerable results. This is reinforced by documentary studies undertaken which show some weaknesses in the educational aspect that the average is still S1, the linearity indicating that the coach and the assistant coach of the majority are not from sports graduates, as well as the license of the majority of local licensing coaches. The feasibility of facilities and infrastructure is statistically getting good results. The availability of tools and training sites was met, but based on observations and interviews, it was found that there were still some equipment damaged, most of them samsak, unkempt workouts, such as broken boxing rings and sports labs that could no longer be used.Based on the results of interviews and documentation of the implementation of special coaching financing for athletes has been running in accordance with the instructions, it's just that the budget disbursement process sometimes faces obstacles because the trainer program is hampered due to delayed funding from the center, some of the trainer program does not run in accordance with the planned schedule, one Example try out try out implementation must run before the national champion But what happens is opposite instead of the new National Championship try out.

\section{Process Evaluation}

Based on the results of interviews and observations of training programs that have been prepared by the trainers have not been fully implemented in the field, so that training provided by trainers to athletes PPLP sports martial arts South Sulawesi not cascading. The training program developed by the trainer is only an administrative requirement reported to the PPLP manager of South Sulawesi.

In the aspect of athlete activity statistically get good result. The PPLP athlete in addition to being a student is also an athlete. They have to attend school and have to train hard in the morning and afternoon. Trainer activity statistically gets good result, but based on result of observation in running training program of trainer emphasize at ability of individual skill of athlete, less physical ability given in every training session, physical exercise is given only as distraction of exercise and not programmed specifically.

Monitoring and provision of Nutrition, based on interviews and observations, in a day PPLP athletes get a meal 3 times plus 1 snack. Ideally a portion of the meal given 4000 calories per meal. That the space or place to cook the consumption has not been categorized as clean according to the health expert, but unfortunately in the ranks of PPLP manager of South Sulawesi Dispora still no nutritionist as consultation menu of right athlete diet.Coordination, Based on the results of interviews, the process of coordination between PPLP and KONI takes place well, even every activity undertaken by PPLP always involves KONI. It's just that in terms of sponsorship there is still no company that really want to promote PPLP through mass media publications. From the interviews and the documentation of welfare aspects, there are problems related to athlete development both athletes are active and at the time no longer athletes, including athletes in PPLP South Sulawesi. 


\section{Product Evaluation}

At the PPLP athletes in South Sulawesi in sports martial arts statistically get enough results. Achievements obtained decreased significantly, it is seen from the data obtained from the results of Vo2Max tests and each championship that followed. The data obtained from each championship proves that the results achieved by the athletes show the decline in martial arts at each followed and not able to maintain the achievements achieved previously and not able to improve the achievements that have been achieved, especially on the singles event kejayaaran 2012-2014 and Multi Event Namely POPNAS in 2013 which was implemented in DKI Jakarta.Based on the evaluation results on the overall context variables, inputs, processes and products show good results so that, PPLP program of martial arts in South Sulawesi.

\section{REFERENCES}

Albert R. Roberts and Gilbert J. Greene, Smart Workbook of Social Workers, translated Juda Damanik and Cynthia Pattiasina, Jakarta: PT BPK Gunung Mulia, 2009.

Angela Baron \& Michael Armstrong, Human Capital Management (London: Kogan Page,2007).

Arikunto, Suharsimi dan Cepi S. Abdul Jabar. Evaluasi Program Pendidikan: Pedoman Teoretis Praktis Bagi Mahasiswa dan Praktisi Pendidikan. edisi kedua. Jakarta: Bumi Aksara, 2008.

Armstrong, Michael. Amstrong's Handbook of Human Reource Management Practice. Philadelphia: Kogan Page, 2009.

Daniel L. Stuflebaum, et al. Evaluation Model (Khuver Academic Publisher. Singapore. 2000).

-----------Evaluation Theory, Models, dan Applications United States of America, 2007.

Dep.Dik.Nas. Evaluasi Program Sekolah. Yogyakarta: Universitas Negeri Yogyakarta, 2009.

Harvard Business Essentials. Performance Management, (Boston: Harvard Business School Publishing Co. 2006).

Ivancevich, John M. Human Resource Management. 10th edition. New York: McGraw-Hill/Irwin, 2007.

James R. Sanders (Chairman of The Joint Committee on Standards for Educational Evaluation). The Program Evaluation Standards. (London: Sage Publication,Inc, 1994)

John M. Owen, Program Evaluation $3^{\text {rd }}$ edition (Allen \& Unwin: NSW Australia. 2006)

John W. Creswell, Research Design. diterjemahkan oleh Achmad Fawaid (Pustaka Pelajar: Yogyakarta2010).

Marvin C. Alkin, Evaluation Roots, (Sage Publication, Inc: California. 2004).

Ministry of sports and youth. Data and Information PPLP 2011. Jakarta: Deputy of Sports Achievement Improvement. 2011

Michael Armstrong, Armstrong's handbook of performance management (London: Kogan Page, 2009). 